\title{
English(es) and Outer Circle Learner: Opportunities and Challenges
}

\author{
Dr. Abdel Rahman Abdalla Salih \\ Associate Professor, Department of English Language and Literature \\ Al-Zahra College for Women, Muscat \\ abdelrahman@zcw.edu.om
}

\begin{abstract}
The phenomenal spread and growth of English in recent years and its eventual dominance in the international arena has represented unprecedented challenges and opportunities to the practice of English Language Teaching (ELT) and learning, particularly in the ESL/EFL contexts. This paper examines the implications of the phenomenal spread of English around the world on the learning experience and preferences of English as foreign language (EFL) learners. A total number of (108) undergraduate students in an institution of higher learning in the Sultanate of Oman took part as data source by responding to a questionnaire survey administered to them. The study specifically explores the challenges 'outer circle' learners face in learning varieties of English and the effects of that on their views and learning a particular variety of English. The paper draws conclusion on the significance of understanding the nature of codes learners use and get exposed to.
\end{abstract}

Keywords: Englishes, outer circle, non-native speaker, English language teaching

\section{INTRODUCTION}

The story of English is an interesting and intriguing subject as its history is full of events that shaped its development and growth. From the time of its introduction to the British Isles in the fifth century by the Anglo-Saxons, English language has developed a long history of growth motivated by mixed changes and complex interaction and with many spoken languages in the world. Historians of English (such as Algeo \& Pyles, 2010; Millward \& Hayes, 2012 among others) have divided the history of English language into three major distinct periods, namely Old English (450-1150), Middle English (1150-1500), and Modern English (1500-) each of which has its own features and peculiarities leading to the subsequent period. These three phases are interrelated and overlapping and are often referred to as 'periods' and 'varieties', thus, "a better way to look at the shifting varieties of English is to think of a continuum of overlapping varieties all of which have been changing but to different degrees" (Winkler, 2012,168).

English has shown a remarkable ability to change and adapt to different cultural and political events and circumstances. It could be argued that, openness to change and growth is one of the key features that distinguish English from many world's languages. In the course of development, English has survived the Norman Conquest in the twelfth century marking a significant period in its history. Many historians of English regarded the Norman Invasion of England in the Middle English period as an important event of great effects. Baugh \& Cable (2013) suggested that "the Middle English period (1150-1500) was marked by momentous changes in the English language, changes more extensive and fundamental than those that have taken place at any time before or since" (152). Even in the Modern time English has shown significant ability to deal with various socio-cultural, political and technological factors that contribute to its growth and development. And this salient characteristic of openness to change gives the language the ability to expand in geography and speakers. In this regard,the emergence of England as a colonial power in the seventeenth century has marked a decisive point in the spread of English globally. 
Moreover, language contact was imminent with "the first diaspora involved relatively large-scale migrations of mother tongue English speakers from England, Scotland, and Ireland predominantly to North America, Australia, and New Zealand" (Jenkins, 2015,6).In the subsequent centuries English expanded its influence and acquired more colonies in many parts of the world. Millward\& Hayes (2012) stated that "conversely, colonization and commerce led to the spread of English around the globe and ultimately to the present position as the most widely used language in the world after Mandarin Chinese" (222). Therefore, an obvious aftermath of the British Empire expansion through the colonial period is the emergence of varieties of English or Englishes where the language is either used as a mother tongue or as a second language or additional language. Kirkpatrick (2010) stated that "thus we can now talk about the different varieties of English across many parts of the world, including many African countries, in the subcontinent, across Asia and in the Caribbean", and that "we can also talk about the different varieties of English which exist within each country where English has become institutionalized" (1).

On the other hand, Crystal (2002) reported that statistics reveal that English has over 400 million users who speak it as their first language. However, this population is outnumbered by those who speak English as a second language. Kirk patrick remarked that "it is commonly accepted that there are now many more people who speak English as a second or later language than there are native speakers of it" (1). This phenomenal growth of English into varieties spoken by many people and serving different purposes of use was described by Kachru, according to Cook (2003), who "describes this situation as one in which English exists in three concentric circles: the inner circle of the predominantly English-speaking countries; the outer circle of the former colonies where English is an official language; and the expanding circle where, although English is neither an official nor a former colonial language, it is increasingly part of many people's daily lives" (27).

Moreover, the rise of English as a language spoken almost everywhere in the world, according to Baugh \& Cable (2002), together with its the growth of the language in the number of speakers and use as a language of international communication gave English a very important position in the world. On the other hand, the extensive and continuous attention of researchers in English and inthe study of its varieties together with the growing population of its speakers made it exceptional. This is true because, English language has an intriguing history of growth and change, diversity, dominance and popularity. The following section explores the implications of the spread of English for its learning and use.

\section{Spread of English: Opportunities and Implications}

If the Old English period was described as the beginning of the language, and Middle English as a period of remarkable change, the Modern Period can be described as a period of continuous change, expansion and dominance. The rise of English to the status of a world-dominant language is shaped by a variety of social, cultural, economic and political factors. Crystal $(2003,59)$ argued that "the present-day world status of English is primarily the result of two factors: the expansion of British colonial power, which peaked towards the end of the nineteenth century, and the emergence of the United States as the leading economic power of the twentieth century".

In the same vein, Cook (2003) suggested that the rapid growth of English in recent years has been honed by a remarkable expansion of international business and communication, the Internet, film industry, international education, tourism and television programmes which all called for extensive use of English. Thus, the twentieth century was significant for English to further expand in geography and acquire more speakers. Davies (2005) stated that "in 1900 English was almost exclusively the language of the British Empire and the US, but after 1950 it was to become the main medium of communication for thousands of organizations worldwide, for broadcasting, the press, advertising, the film and music industries, the academic community, international transport and communications" (35).

The recent development of English has serious implications on the world's linguistic map, the English Language Teaching (ELT) practice, and the concept of 'native speaker'. The rapid development of English may have 
serious consequences on some minor languages leading to their extinction. In addition, the spread of English worldwide has challenged the traditional concept of 'native speaker' and changed the ELT practice in material and methodologies. Researchers such as (Baugh \& Cable, 2013; Winkler, 2007; Crystal 2003, \& Davies, 2005) have also questioned the future of English and its dialects. The dynamic proliferation of English worldwide has gone in tandem with the increasing demand for the language by its users in the Outer and Expanding Circle countries. Such a complex interaction has put significant impact on the learning experience and teaching practice of the language. This is true because the rapid development and distribution of English in recent years has been closely related to the history of English Language Teaching (ELT).

Furthermore, the distribution of English and its development motivated innovations in the ELT practices. Such a phenomenon was observed by Cook (2003) who stated that "different approaches to teaching English did not just occur by chance, but in response to changing geopolitical circumstances and social attitudes and values, as well as to shifts of fashion in linguistics which, for all its apparent objectivity, was itself subject to social change" (30). Thus, the development of English has oiled progressive change in the teaching and learning of English particularly in the nonnative-English speaking countries and by speakers of other languages who continue learning and mastering it for varieties of reasons and purposes. The status of English in the Outer and Expanding Circle countries has been an area of interest for researchers in the last decade or so, especially with the emergence of concepts such as native speakers and nonnative-English speakers and the debate that revolves around them (Park, 2012; Braine, 2010; Cook, 2003). If research has called for the significance of understanding the experience of teachers in teaching English to speakers of other languages-TESOL (Park 2012), it could be argued that it is of paramount importance also to explore the experience and attitudes of nonnative-English speaker learners in the Outer Circle and Expanding Circle. This issue, unfortunately, has not received researchers' extensive attention.

This paper explores the consequences of the rapid growth of English worldwide on the ELT situation. The study investigates the learners' experience and their awareness of their identity as nonnative speakers of English as well as their perceptions towards the varieties of English used in various communicational contexts. It specifically attempts to address the following issues:

1. How do learners of English view itsrole in their circle?

2. How do students perceive varieties of English today?

3. What challenges do students encounter while learning English?

\section{Methodology}

\section{Samples}

The subjects of this study comprised a group of(108) undergraduate students at an institute of higher learning in the Sultanate of Oman. These students were non-native English speakers aged 20 and 22 majoring in English language and literature. In terms of proficiency, these students have successfully completed the General Foundation Programme (GFP) English Proficiency courses in addition to an IELTS Preparatory Test which qualified them to join the Department of English Language and Literature.

\section{Procedures}

This study utilised one source of data: a questionnaire survey (Appendix) distributed among undergraduate students taking English as a major course. The procedures for data collection were discussed as follows: 
Questionnaire

The procedures for data collection were discussed as follows:

Following the authorities in the field (e.g., Karavas-Doukas, 1996; Hedgcock\&Lefkowitz, 1996) a questionnaires was designed by the researcher to explore the impact of the spread of English on its learners' experience in terms of opportunities and challenges as perceived by these learners and their tutors. The questionnaire was also administered to understand the students' knowledge and awareness of the current status of global Englishes, and the relevance of varieties of English in constructing ELT realities and learner identity as well their expectations of indulging in learning English. The questionnaire (Appendix) consisted of 15 items designed to explore the informants' knowledge of and attitudes toward the current status of English as a global language, the perceived possible opportunities created by the spread of English, preferences toward the two major national varieties of English spoken in the inner circle and knowledge of other varieties of English, as well as the challenges students may deem imminent. The questionnaire items were arranged randomly, and next to the itemswere five columns with five options: Strongly Agree, Agree, Uncertain, Disagree, and Strongly Disagree. The numbers 5, 4, 3, 2, and 1 were given to the five answer options respectively. The informants were told to choose the items they prefer by placing a tick in the box. Respondents' degree of agreement or disagreement with each item is measured against their selection. In addition, the questionnaire contained a space for the participants to add other challenges they face in learning English. The questionnaire was distributed to the informants during lectures-break and later collected for further analysis.

\section{Data AnAlysis}

\section{Analysis of Questionnaires Data}

To serve its end, the study analyzed the data collected via thequestionnaire distributed to English language and literature students in an institution of higher learning in the Sultanate of Oman.The questionnaire focused on the opinions of EFL learners on the significance of the global spread of English for the learning opportunities and challenges encountered by these learners.

\section{RESUltS AND Discussion}

\section{Students' Questionnaire}

The questionnaire items were regrouped thematically for easier discussion. The results of the analysis of the students' questionnaire were categorised and discussed under the informants' awareness of the status of English, relevance of English, learning opportunities, preferences towards varieties of English, and challenges as shown below:

\section{Knowledge of the status of English}

Table 1 below shows the informants' perceptions about the current status of English.

Table 1. Students' questionnaire frequency count and percentage equivalent

\begin{tabular}{|l|c|c|c|c|c|}
\hline & $\begin{array}{c}\text { S.A } \\
f \%\end{array}$ & $\begin{array}{c}\text { A } \\
\text { f\% }\end{array}$ & $\begin{array}{c}\text { U } \% \\
\text { Statement(s) responded to: }\end{array}$ & $\begin{array}{c}\text { S.D } \\
\text { f\% }\end{array}$ & $\begin{array}{c}\text { D } \\
\text { f\% }\end{array}$ \\
\hline $\begin{array}{l}\text { 1. English is the most widely spoken language } \\
\text { in the world. }\end{array}$ & $74(69)$ & $25(23)$ & $2(2)$ & $1(1)$ & $6(6)$ \\
\hline
\end{tabular}

Results of the analysis of the respondents' response to item (1) in the students' questionnaire reveal that $69 \%$ strongly agreed and 23\% agreed that English is enjoying global dominance in terms of speakers and use. On the other hand, $2 \%$ of the participants were uncertain about their stand, while $1 \%$ strongly disagreed and $6 \%$ disagreed with the statement. This finding indicates that students are aware of the global status of English and 
its presence as a world's major language. This finding confirms Cook's (2003) observation about the rapid growth and spread of English in the global arena when he stated that "whereas, in the past, English was but one international language among others, it is now increasingly in a category of its own" (p.25).

\section{Relevance of English}

Table 2 below presents the informants' attitudes towards English and its relevance to their learning experience.

Table 2. Students' questionnaire frequency count and percentage equivalent

\begin{tabular}{|l|c|c|c|c|c|}
\hline & $\begin{array}{c}\text { S.A } \\
\text { f\% }\end{array}$ & $\begin{array}{c}\text { A } \\
f \%\end{array}$ & $\begin{array}{c}\text { U } \\
f \%\end{array}$ & $\begin{array}{c}\text { S.D } \\
\text { f\% }\end{array}$ & $\begin{array}{c}\text { D } \\
f \%\end{array}$ \\
\hline $\begin{array}{l}\text { Statements responded to } \\
\text { 2. Learning English is necessary for me. }\end{array}$ & $79(73)$ & $18(17)$ & $6(6)$ & - & $5(5)$ \\
\hline $\begin{array}{l}\text { 3. Learning English and be able to use it effectively } \\
\text { enables me to communicate with people in the world. }\end{array}$ & $55(51)$ & $41(38)$ & $5(5)$ & $4(4)$ & $3(3)$ \\
\hline $\begin{array}{l}\text { 4. I feel comfortable to use English with my friends. } \\
\text { 5. I feel proud to communicate in English with } \\
\text { foreigners. }\end{array}$ & $31(29)$ & $40(37)$ & $25(23)$ & $8(7)$ & $4(4)$ \\
\hline 9. I can follow classes conducted in English. & $28(26)$ & $53(49)$ & $20(19)$ & $4(4)$ & $3(3)$ \\
\hline
\end{tabular}

Table 2 above reveals that in responding to item (2), 73\% strongly agreed and 17\% agreed that learning English is necessary for them, while $5 \%$ of the participants disagreed with the view about learning English as necessary for them. On the other hand, the participants' response to item (3) reveals that $51 \%$ strongly agreed, and 38\% agreed that learning English and mastering it prepares them for effective communication with people around the world. However, $5 \%$ were uncertain, while $4 \%$ strongly disagreed, and $3 \%$ disagreed with the same statement. The participants also responded to item (4) where $29 \%$ strongly agreed, and $37 \%$ agreed that they felt comfortable communicating with friends in English. The 'uncertain' informants represented $23 \%$ of the subjects, while $7 \%$ strongly disagreed and $4 \%$ disagreed that they felt comfortable to use English with their friends. When asked about their confidence in communicating with foreigners in English (item 5), 48\% of the participants strongly agreed, and 33\% agreed that they felt proud to speak to foreigners using English. On the other hand, $11 \%$ were uncertain, $2 \%$ strongly disagreed and $6 \%$ disagreed that they felt proud communicating with foreigners in English.

The informants' response to item (9) reveals that 26\% strongly agreed, and $49 \%$ agreed that they could follow classes conducted in English. 20\% were uncertain, while 4\% strongly disagreed, and 3\% disagreed that they could follow classes run in English. Results here show that the EFL learners have positive attitudes towards English as a language that plays significant roles in their life and future. In addition, the participants were aware of the role of English as an international lingua franca that it enables them to communicate with speakers of other languages. Another important observation is that students practice English in situations outside classrooms and for other social and communicative functions. This finding is significant because learners of English today especially in EFL settings, have wider practices for the language which in the turn will improve their proficiency and communicative abilities and strengthen the motivation they have in communicating with non-Arabic speakers. These new emerging trends call for serious consideration into the teaching methods in ELT classes as well the necessity of exploiting the co-curricular activities for creating more language practice platforms. 
English(es) and Outer Circle Learner: Opportunities and Challenges

Learning Opportunities

Table 3 below presents the learning opportunities and resources available as perceived by the students.

Table 3. Students' questionnaire frequency count and percentage equivalent

\begin{tabular}{|l|c|c|c|c|c|}
\hline & $\begin{array}{c}\text { S.A } \\
f \%\end{array}$ & $\begin{array}{c}\text { A } \\
f \%\end{array}$ & $\begin{array}{c}\text { U } \\
f \%\end{array}$ & $\begin{array}{c}\text { S.D } \\
f \%\end{array}$ & $\begin{array}{c}\text { D } \\
f \%\end{array}$ \\
\hline $\begin{array}{l}\text { Statements responded to } \\
\text { 6. It is easy to find information about English. }\end{array}$ & $41(38)$ & $44(41)$ & $16(15)$ & $3(3)$ & $4(4)$ \\
\hline 7. The Internet motivates me to learn English. & $43(40)$ & $35(32)$ & $20(19)$ & $8(7)$ & $2(2)$ \\
\hline 8. Mobile Phones are useful in learning English. & $54(50)$ & $30(28)$ & $15(14)$ & $4(4)$ & $5(5)$ \\
\hline
\end{tabular}

Table 3 above presents the informants' opinions on the learning of English opportunities they perceive available. In their response to the accessibility of information about English (item 6), 38\% strongly agreed, and 41\% agreed that they could easily access information about English, while 15\% remained uncertain and 3\% strongly disagreed and 4\% disagreed with the statement. Item (7) explores the role of the Internet in learning English. $40 \%$ of the informants strongly agreed, and 32\% agreed that the Internet motivates them to learn English, while $19 \%$ were uncertain about their stand, and $7 \%$ strongly disagreed and $2 \%$ disagreed that the Internet motivated them to learn English. This result shows that EFL learners utilise online sources and materials in their learning. Thus, bringing in the Internet and its applications into language classrooms and making it an integral part of the students' learning experience is deemed imperative. In the same vein, item (8) explored the use of mobile phones by students in learning English. 50\% of the informants strongly agreed, and 28\% agreed that mobile phones are useful in learning English. On the other hand, 14\% were uncertain, while 4\% strongly disagreed, and 5\% disagreed with the view of usefulness of mobile phones for learning English. The overall results here show that EFL learners have better learning opportunities and access to data on English available online and in various forms, as well as other technological devices which support their language learning bid, and vary their learning strategies as well. Furthermore, the Internet as a new medium with vast applications has offered English language learners and users the opportunity to contribute to and follow closely any change that may take place in the language system. Crystal (2000) argued that "the speed with which Internet usages are taken up is unprecedented in language change-another manifestation of the influence of the technology on English" (140).An obvious implication is that learners of English today are not only offered with greater learning opportunities, but also exposed to a technology-led language change.

\section{Students' Attitudes towards varieties of English}

Table 4 summarises the students' attitudes towards varieties of English and their preferences towards these varieties.

Table 4. Students' questionnaire frequency count and percentage equivalent

\begin{tabular}{|c|c|c|c|c|c|}
\hline & $\begin{array}{l}\text { S.A } \\
\text { f\% }\end{array}$ & $\begin{array}{c}A \\
f \%\end{array}$ & $\begin{array}{c}U \\
f \%\end{array}$ & $\begin{array}{l}\text { S.D } \\
\text { f\% }\end{array}$ & $\begin{array}{c}D \\
f \%\end{array}$ \\
\hline $\begin{array}{l}\text { Statements responded to } \\
\text { 10. British English is easier than American English. }\end{array}$ & $28(26)$ & $40(37)$ & $25(23)$ & $13(12)$ & $2(2)$ \\
\hline 11. American English is easier than British English. & $24(22)$ & 21(19) & $44(41)$ & 12(11) & $7(6)$ \\
\hline 12. People speak varieties of English. & $30(28)$ & $43(40)$ & $23(21)$ & $9(8)$ & $3(3)$ \\
\hline $\begin{array}{l}\text { 15. Learning other varieties of English is necessary } \\
\text { in our life. }\end{array}$ & $30(28)$ & $39(36)$ & $22(20)$ & $9(8)$ & $8(7)$ \\
\hline
\end{tabular}

The informants' preferences and views towards varieties of English are summarised in Table 4 above. On their 
views about the two major national varieties of English (item 10), 26\% strongly agreed, and 37\% agreed that British English is easier to study and use than the American English; while 23\% were uncertain, 12\% strongly disagreed, and $2 \%$ disagreed with the same view. Item (11) explored the students' perceptions about the American English variety, where 22\% strongly agreed, and 19\% agreed that American English is easier than British English. The results also showed that $41 \%$ were uncertain, $11 \%$ strongly disagreed, and $6 \%$ disagreed that they preferred American English over British English. On their awareness of other varieties of English, item (12) reveals that $28 \%$ of the informants strongly agreed, and $40 \%$ agreed that people use varieties of English, while 21\% reported uncertainty about the same idea, $8 \%$ strongly disagreed, and 3\% disagreed with the existence of varieties of English. In recognising the importance of other varieties of English item (15), 28\% of the informants strongly agreed, $36 \%$ agreed, while $20 \%$ were uncertain that learning other varieties of English is necessary for them. $8 \%$ of the informants strongly disagreed, and $7 \%$ disagreed that it is necessary to learn other varieties of English. With the internationalisation of English and emergence of its varieties in recent decades, it is imperative to understand the nature of EEL classrooms when it comes to which variety is used. This urgent and pressing issue should be a major concern of ELT research. Crystal (2002) noted that "a much more intriguing question is to ask what is happening to English in countries where people don't use it as a mother tongue". Thus, investigating the different status English has and varieties of purposes it serves in the more complex bilingual or even multilingual EFL contexts, is "a highly complicated question, as it turns out" (2).

\section{Perceived challenges}

Table 5 below highlights the informants' challenges pertaining to learning English.

Table 5. Students' questionnaire frequency count and percentage equivalent

\begin{tabular}{|l|c|c|c|c|c|}
\hline & $\begin{array}{c}\text { S.A } \\
f \%\end{array}$ & $\begin{array}{c}\text { A } \\
f \%\end{array}$ & $\begin{array}{c}\text { U } \\
f \%\end{array}$ & $\begin{array}{c}\text { S.D } \\
f \%\end{array}$ & $\begin{array}{c}\text { D } \\
f \%\end{array}$ \\
\hline $\begin{array}{l}\text { Statements responded to } \\
\begin{array}{l}\text { 13. The Internet has made reading English } \\
\text { books less important. }\end{array}\end{array}$ & $22(20)$ & $29(27)$ & $35(32)$ & $19(18)$ & $3(3)$ \\
\hline $\begin{array}{l}\text { 14. It is difficult to understand speakers of other } \\
\text { varieties of English. }\end{array}$ & $18(17)$ & $33(31)$ & $43(40)$ & $13(12)$ & $1(1)$ \\
\hline
\end{tabular}

Table 5 above presents the informants' opinions on the perceived challenges pertaining to learning English. Focusing on the disadvantages of the Internet, item (13) reveals that $20 \%$ of the informants strongly agreed, and $27 \%$ agreed that the Internet has reduced their interest in reading books in English. On the other hand, $32 \%$ were responded as 'uncertain', while 18\% strongly disagreed, and 3\% disagreed that the Internet has made reading English books less important. Item (14) explored another perceived challenge by EFL learners. 17\% of the informants strongly agreed, and 31\% agreed that they had difficulty in understanding speakers of the diverse varieties of English. However, 40\% expressed 'uncertainty' about their stand, 12\% strongly disagreed, and $1 \%$ disagreed with the same view. The challenges EFL learners encounter may vary from a learning context to another depending on a number of factors such as learners themselves, the learning environment, the teaching methods, and social attitudes towards English language and its learner, among others. The students have also commented on certain perceived challenges they face in learning English. These challenges were categorised in the following table. 
English(es) and Outer Circle Learner: Opportunities and Challenges

Table 6. Learning challenges identified by students

\begin{tabular}{|l|l|}
\hline \multicolumn{1}{|c|}{ Areas of challenge } & \multicolumn{1}{c|}{ Aspects of challenge } \\
\hline vocabulary & $\begin{array}{l}\text { Meaning of new lexical items, lexical differences among varieties of English, ability } \\
\text { to use new items in various contexts, spelling. }\end{array}$ \\
\hline pronunciation & Discrepancy between sounds and spelling of words. \\
\hline grammar & Applying rules in writing and speaking \\
\hline writing & Essay structure, lack of vocabulary, recognizing various writing genres. \\
\hline communication & $\begin{array}{l}\text { Lack of confidence, lack of practice, fear to speak to others in English, avoidance of } \\
\text { speech mistakes. }\end{array}$ \\
\hline Varieties of English & Diverse accents of speakers, vocabulary differences \\
\hline Study skills & EAP, difficulty of some courses in English, understanding fully lectures. \\
\hline
\end{tabular}

Table 6 above shows the common challenges many EFL students face, especially the ones that concern with the structure of English. It is usual to see EFL learners report learning difficulties in areas such as new vocabulary items, pronunciation, spelling and grammar. One of the students commented that "I facedsome problems in learning English such as forgetting the vocabulary I learned". Another student explained that "we face many challenges first, we cannot understand many words when we study and we face challenges in reading". Commenting on their experience in learning vocabulary, one of the students reported that it is "hard to memorize new words and feel hard to use them". However, a significant observation that needs further attention is the lack of practice in English as a challenge that hinders many learners' learning. One of the students reported that "sometimes I have some difficult words or pronunciation when I communicate with others because we have less practice. In other word, we don't do more practice in speaking". Another student stated that it is challenging when "communicating with foreigners, because we do not use English always, so we face difficulties speaking with foreigners. Even though we have good vocabulary and grammar, but we do not have the chance to speak in English".Another student wrote "we don't have practice with our friends or family just we study the language (English) in college".The same view was shared by another student who stated that "we do not do practice for English just we have the class in college so learning English language will be a big challenge to learn it fast". The students' feedback on their experience in learning English suggests that the challenges these learners face will have implications on their learning experience and their confidence as language users able to communicate with others. Many students reported that one of the reasons for their inability to speak well in English is the absence of practice which affects their communicative skills and using English in various social contexts and for different purposes and functions. The challenges EFL learners encounter need to be identified, investigated and addressed and proper solutions must be provided. In addition, it is of paramount importance to identify EFL learners' needs in relation to the emerging trends of English as a lingua franca and varieties in higher education. Given the direct impact of the Internet and technology in the process of English language change in areas such as vocabulary, spelling and pronunciation, ELT practice needs to adjust its philosophy, and conform to the new norms of English its learners get exposed to and bring into the learning context.

\section{CONCLUDING REMARKS}

As a concluding statement, it is a pertinent fact that the rapid growth of English and its accelerated development by a number of factors in recent years has brought about significant insights into the ELT practice in general, and EFL in particular. New classroom realities have emerged in response to the changing environments including learners themselves. Learners of English today, particularly in the outer circle countries, are seen to have constructed new identities in response to the strong impact global Englishes put on the learning map. In 
addition, learners have better learning opportunities as a result of the close association between English and the Internet and technology. However, with this privilege comes a set of challenges learners face which require a deeper understanding of the nature of the objectives EFL learners have for learning the language as well as the necessary adjustments needed in the processes of course design, materials development and teaching methodology. Such a realisation is significant in helping these students maximize their learning. By doing so, we move a step forward and attempt to contribute to the urgency for exploring, sustaining and renewing ELT for the next generations of English language learners.

\section{REFERENCES}

Algeo, J\&Pyles,T. (2010).The Origins and Development of the English Language.( $6^{\text {th }}$ edition) Brazil: Wadsworth Cengage Learning.

Bough, C\& Cable, T. (2013). A History of the English Language. ( $6^{\text {th }}$ edition) New York: Pearson.

Cook, G, (2003). Applied Linguistics. Oxford: Oxford University Press.

Crystal, D. (2002). The English language: A Guided Tour of the Language. ( $2^{\text {nd }}$ Ed.). London: Penguin.

Crystal, D. (2003). English as a Global Language. ( $2^{\text {nd }}$ Ed.). Cambridge: Cambridge University Press.

Davies, D.(2005). Varieties of Modern English. New York: Person Longman.

Hedgcock, J. \&Lefkowitz, N. (1996). 'Some input on input: Two analyses of student response to expert feedback in L2 writing'. The Modern Language Journal, (80), 287-308.

Jenkins, J. (2015). Global Englishes: A Resource Book for Students. (3rd ed.). London: Routledge.

Karavas-Doukas, E. (1996). 'Using Attitude scales to investigate teachers' attitudes to the communicative approach. English Language Journal, 50(3), 187-198.

Kirkpatrick, A. (ed.) (2010). The Routledge Handbook of World Englishes. London and

New York: Routledge.

McGregor, W. (2009). Linguistics: An Introduction. New York: Continuum.

Millward, C., and Hayes, M. (2012). A Biography of the English Language (3rd ed.). United Kingdom: Wadsworth Cengage Learning.

Parker, F \&Riley, K. (2005).Linguistics: for Non-Linguists. New York: Person.

Winkler, E. (2007). Understanding Language. New York: Continuum.

\section{(APPENDiX: StUdents' Questionnaire)}

\section{Dear students:}

Directions: In this questionnaire, you will find statements about you and what you think. For each statement, you should choose the one you think is best. Kindly be informed that the questionnaire is conducted for research purposes only and your answers will be dealt with confidentially.

Please respond to All the items in this questionnaire.

I thank you in advance for your cooperation and help with this research.

Please respond to the following statements by placing a tick ( $\checkmark$ ) mark in the box that represents your attitude.

$$
\text { 5= Strongly Agree } \quad 4=\text { Agree } \quad 3=\text { Uncertain } \quad 2=\text { Disagree } \quad 1=\text { Strongly Disagree }
$$


English(es) and Outer Circle Learner: Opportunities and Challenges

\begin{tabular}{|c|c|c|c|c|c|c|}
\hline & Items & 5 & 4 & 3 & 2 & 1 \\
\hline 1 & English is the most widely spoken language in the world. & & & & & \\
\hline 2 & Learning English is necessary for me. & & & & & \\
\hline 3 & $\begin{array}{l}\text { Learning English and be able to use it effectively enables me to } \\
\text { communicate with people around the world. }\end{array}$ & & & & & \\
\hline 4 & I feel comfortable to use English with my friends. & & & & & \\
\hline 5 & I feel proud to communicate in English with foreigners. & & & & & \\
\hline 6 & It is easy to find information about English. & & & & & \\
\hline 7 & The Internet motivates me to learn English. & & & & & \\
\hline 8 & Mobile Phones are useful in learning English. & & & & & \\
\hline 9 & I can follow classes conducted in English. & & & & & \\
\hline 10 & British English is easier than American English. & & & & & \\
\hline 11 & American English is easier than British English. & & & & & \\
\hline 12 & People speak varieties of English today. & & & & & \\
\hline 13 & The Internet has made reading English books less important. & & & & & \\
\hline 14 & It is difficult to understand speakers of other varieties of English. & & & & & \\
\hline 15 & Learning other varieties of English is necessary in our life. & & & & & \\
\hline
\end{tabular}

*The challenges I face in learning English are:

Citation: Dr. Abdel Rahman Abdalla Salih, "English(es) and Outer Circle Learner: Opportunities and Challenges" American Research Journal of English and Literature, vol 3, no. 1, 2017, pp. 1-10.

Copyright (c) 2017 Dr. Abdel Rahman Abdalla Salih, This is an open access article distributed under the Creative Commons Attribution License, which permits unrestricted use, distribution, and reproduction in any medium, provided the original work is properly cited. 